\title{
Long-Term Observations of Beach Variability at Hasaki, Japan
}

\author{
Masayuki Banno *D, Satoshi Nakamura, Taichi Kosako, Yasuyuki Nakagawa, \\ Shin-ichi Yanagishima and Yoshiaki Kuriyama
}

Port and Airport Research Institute, 3-1-1 Nagase, Yokosuka 239-0826, Japan; nakamura_s@p.mpat.go.jp (S.N.); kosako@p.mpat.go.jp (T.K.); nakagawa@p.mpat.go.jp (Y.N.); yanagishima-maborikaigan@asahi.email.ne.jp (S.-i.Y.); kuriyama@p.mpat.go.jp (Y.K.)

* Correspondence: banno-m@p.mpat.go.jp

Received: 14 October 2020; Accepted: 31 October 2020; Published: 2 November 2020

check for updates

\begin{abstract}
Long-term beach observation data for several decades are essential to validate beach morphodynamic models that are used to predict coastal responses to sea-level rise and wave climate changes. At the Hasaki coast, Japan, the beach profile has been measured for 34 years at a daily to weekly time interval. This beach morphological dataset is one of the longest and most high-frequency measurements of the beach morphological change worldwide. The profile data, with more than 6800 records, reflect short- to long-term beach morphological change, showing coastal dune development, foreshore morphological change and longshore bar movement. We investigated the temporal beach variability from the decadal and monthly variations in elevation. Extremely high waves and tidal anomalies from an extratropical cyclone caused a significant change in the long-term bar behavior and foreshore slope. The berm and bar variability were also affected by seasonal wave and water level variations. The variabilities identified here from the long-term observations contribute to our understanding of various coastal phenomena.
\end{abstract}

Keywords: beach observation; beach morphology; beach profile; long-term measurement; dune; berm; longshore bar

\section{Introduction}

Beaches play an important role in disaster prevention because they significantly reduce wave energy and protect the hinterland from hazards like wave overtopping. They also provide essential environmental functions such as habitats for benthic organisms and fish, and recreational and relaxation sites for people. Thus, beaches have a high environmental and economic value [1]. The accurate prediction of beach morphological changes is an important issue in coastal management and numerical models of morphological change have been developed. The physics-based models (e.g., XBeach [2]) can simulate short-term beach morphological changes such as beach erosion because of storms, but long-term beach morphological changes are difficult to predict by the physics-based models because of the accumulation of errors over time [3]. To predict long-term coastal change, the simplified models, which reproduce a single process such as shoreline change, are more effective. Equilibrium shoreline models (e.g., [4]) and one-line models (e.g., [5]) are often applied to predict long-term coastal changes, and a hybrid model combining the equilibrium and one-line models also has been developed [6].

Observational data of beach morphological changes are used to understand various beach processes (e.g., cyclic beach process [7], longshore bar behavior [8,9], cobble process [10], beach response to El Niño-South Oscillation [11]) and to validate the models [2-6,9]. In recent years, beach observation data covering several decades have become increasingly important for understanding the impacts of future sea level rise and wave climate change on beaches [12]. However, there are few long-term observation 
datasets of beach morphological changes on a multi-decadal scale. Examples of beach observations covering more than 25 years include Duck (USA), where beach morphology has been measured once every two weeks since 1981 [13-15], and Narrabeen-Collaroy (Australia), where measurement has been conducted once a month since 1976 [16-18]. In Japan, scientists have measured long-term beach morphological changes using piers. Beach profiles were measured along piers at the Ogata coast facing the Sea of Japan almost once a month from 1973 [19] and at the Ajigaura coast facing the Pacific Ocean once a week from 1976 [20]. However, both measurement sets ceased when the piers were removed (Table 1).

On the Hasaki coast in Japan facing the Pacific Ocean, beach profiles have been measured along a pier more than once a week since 1986, and many studies have used the observed data (e.g., [7-9,11,21-23]). The measurements at the Hasaki coast are long term and taken at a high frequency compared with those at other sites (Table 1). In this paper, we present the results of long-term observations of beach morphology at Hasaki, and analyze its temporal variability.

Table 1. Examples of long-term beach observation studies, worldwide.

\begin{tabular}{ccccccc}
\hline Site & Country & Obs. Start & Obs. End & Obs. Frequency & \# of Profile & Refs. \\
\hline Hasaki & Japan & 1986 & Continuing & Daily/weekly & 1 & text \\
Duck & USA & 1981 & Continuing & Biweekly & 1 & {$[13-15]$} \\
Narrabeen-Collaroy & Australia & 1976 & Continuing & Monthly & 5 & {$[16-18]$} \\
Moruya & Australia & 1972 & Continuing & Monthly & 4 & {$[24-26]$} \\
Ogata & Japan & 1973 & 2008 & Monthly & 1 & {$[19]$} \\
Ajigaura & Japan & 1976 & 1998 & Weekly & 1 & {$[20]$} \\
\hline
\end{tabular}

\section{Materials and Methods}

\subsection{Study Site}

The Hasaki coast is a microtidal sandy beach located in eastern Japan facing the Pacific Ocean (Figure 1a). The beach is a longshore uniform beach (Figure $1 \mathrm{~b}$ ), which extends $16 \mathrm{~km}$. The median grain size of the foreshore sediment is approximately $0.18 \mathrm{~mm}$ and the porosity is approximately $39.5 \%$ [27]. The mean high water springs (MHWS), mean sea level (MSL) and mean low water springs (MLWS) at the Hasaki coast are $1.25 \mathrm{~m}, 0.65 \mathrm{~m}$, and $-0.20 \mathrm{~m}$, respectively. The Hasaki Port Datum Line was used for the elevation in this study. Kashima Port is located on the north end of the coast and the mouth of the Tone River is located at the south end of the coast. The shoreline position has been relatively stable over the past 30 years for most of the coast, although there were some local trends in shoreline changes around port facilities at the north end and T-head groynes on the southern side of the coast because of longshore sediment transport [28]. The structures are located more than $4 \mathrm{~km}$ away from the pier described below, and the pier is considered to be far enough away from these structures that they will not influence the shoreline changes at the pier. 


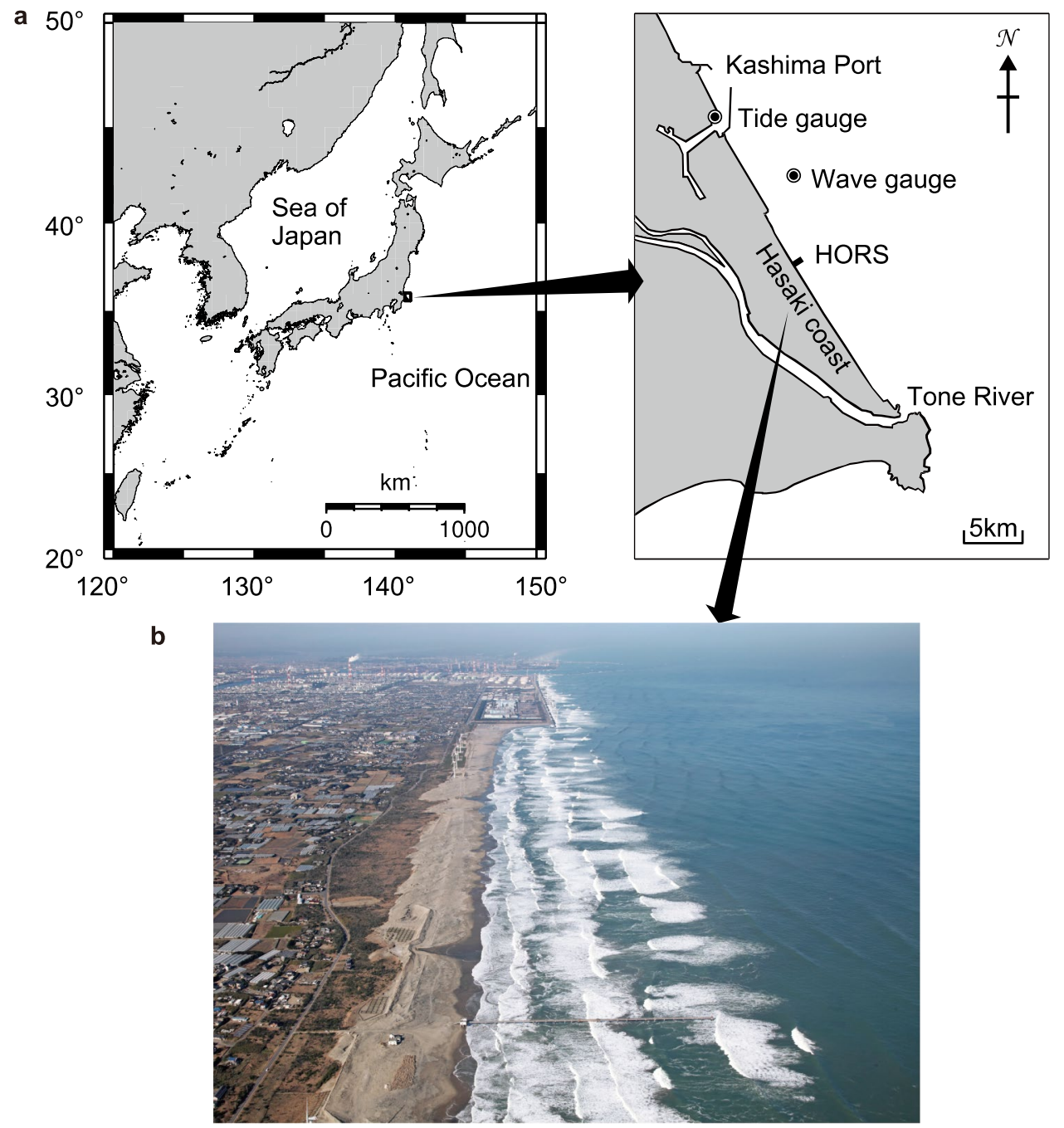

Figure 1. Hasaki coast. (a) The locations of the Hasaki coast, showing the locations of the Hazaki Oceanographical Research Station (HORS), the wave gauge and the tidal gauge; (b) aerial photo of the coast taken with the HORS pier.

\subsection{The Pier}

Long-term beach profile measurements have been conducted along the pier $\left(35^{\circ} 50^{\prime} 27^{\prime \prime} \mathrm{N}\right.$, $140^{\circ} 45^{\prime} 41^{\prime \prime} \mathrm{E}$ ), which is located approximately $4 \mathrm{~km}$ from the northern end of the Hasaki coast. The pier and a research building on the land side form the Hazaki Oceanographical Research Station (HORS). The pier extends offshore perpendicular to the shoreline, and it is around $400 \mathrm{~m}$ long (Figure 1b); the design length is $427 \mathrm{~m}$ including the slope for the entrance. The pier is basically a single-pile structure with a diameter of $0.8 \mathrm{~m}$ to minimize the impact of scouring around the piles as much as possible, and the cross-shore interval of the piles is $15 \mathrm{~m}$. The pier at Duck, USA, has piles of $0.9 \mathrm{~m}$ in diameter at $12.2 \mathrm{~m}$ intervals, and scour had been observed around the piles [29]. The design of the pier at the Hasaki coast reflects the observed morphological change at Duck. Although some scouring has been observed also around the piles of the Hasaki's pier, the bathymetry around the pier is relatively uniform for the longshore direction as seen in Figure 2. Kuriyama [30] also showed that the impact of scouring on the beach profile change was small. 


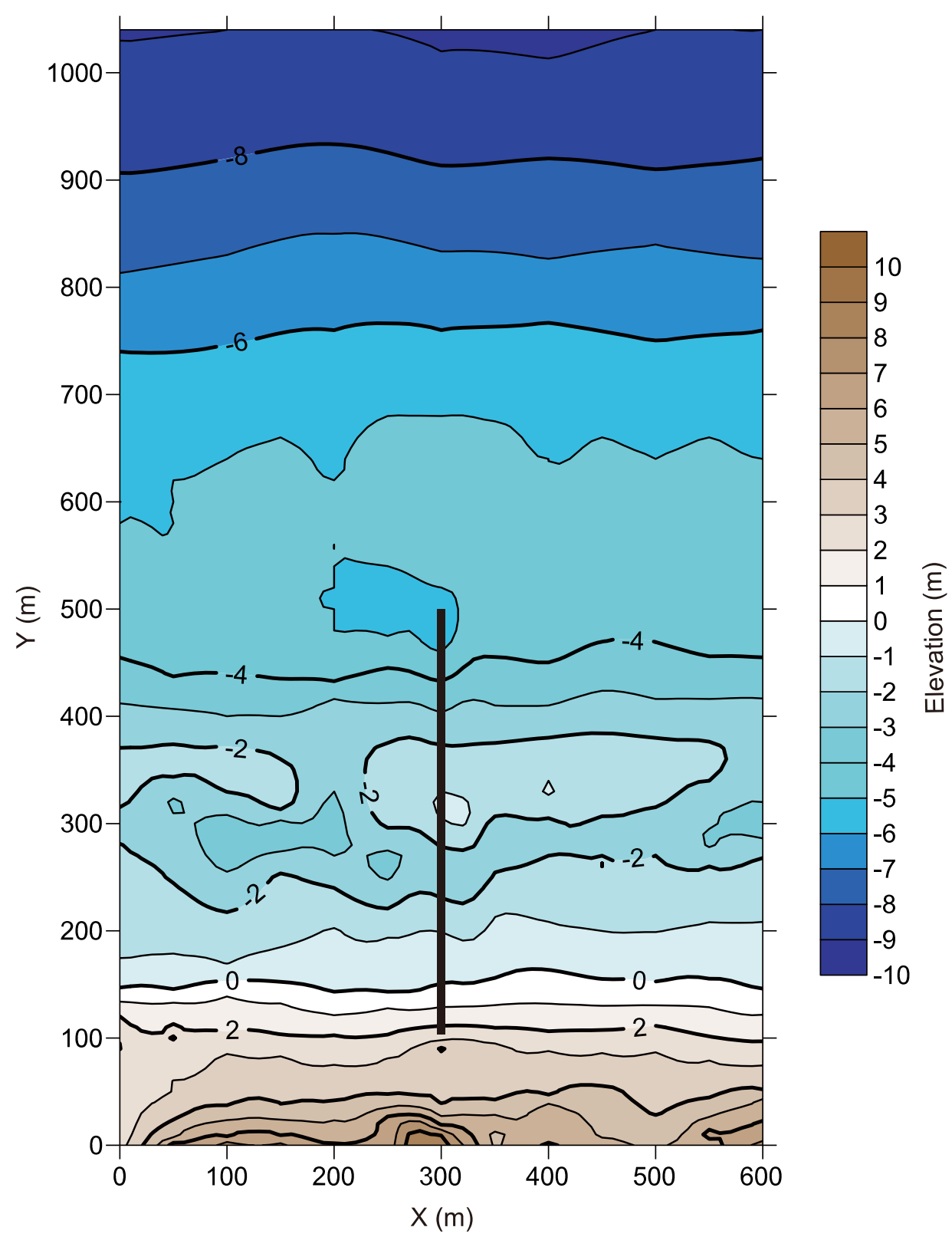

Figure 2. The bathymetry around the pier on February 15, 2020.

\subsection{Method of Beach Profile Measurement}

Long-term beach profile observations on the Hasaki coast were made every weekday from March 12, 1986 to March 31, 2011, and have been made once a week since April 2011. The beach profiles were measured with one survey line along the pier. The total cross-shore length of the measurement was $500 \mathrm{~m}$, consisting of $115 \mathrm{~m}$ on land and $385 \mathrm{~m}$ along the pier (underwater) at intervals of $5 \mathrm{~m}$. We used the cross-shore coordinates with the base of the pier as P0 $\mathrm{m}$ and refer to the measurement section as $\mathrm{P}-115 \mathrm{~m}$ to $\mathrm{P} 385 \mathrm{~m}$. The profiles from P0 $\mathrm{m}$ to P385 $\mathrm{m}$ were measured from the pier using a 3-kg or 5-kg-lead-weight line, and the profiles from $\mathrm{P}-115 \mathrm{~m}$ to $\mathrm{P}-5 \mathrm{~m}$ were measured using a level staff. The elevations at the measurement points close to the piles were also measured from March 1986 to June 1993 and from April 2011 to the present. However, the data are just used as reference data because local scouring was considered to be present. In this study, the data at the measurement points close to the piles (i.e., at P100 m, P105 m, P165 m, P175 m, P200 m, P205 m, P220 m, P235 m, P250 m, P265 m, 
P280 m, P295 m, P310 m, P325 m, P340 m, P355 m, P370 m) were linearly interpolated from the data at the previous and subsequent measurement points.

\subsection{Wave and Water Level Measurement}

Sea-water levels were measured at hourly intervals by a float-type tide gauge in Kashima Port (Figure 1a). Deepwater significant wave heights and periods were measured every $20 \mathrm{~min}$ to $2 \mathrm{~h}$ (2-h intervals in 1986-2007, hourly in 2007-2009 and 20-min intervals from 2010) using a seabed-mounted ultrasonic wave gauge at a water depth of $24 \mathrm{~m}$ off Kashima Port (Figure 1a). In this study, we used the water levels observed from January 1, 1986 to December 31, 2010, and the deepwater significant wave heights and periods observed from January 1, 1986 to December 31, 2018. The water level data after 2011 were not included in this paper because of a lack of detailed quality checks.

Where hourly data were missing between 1986 and 2010, the water levels were interpolated based on the deviations between astronomical predicted and actual water levels before and after the missing data points. The missing data of the deepwater wave were interpolated from the observed wave height and period at the Hitachinaka Port, which is located around $50 \mathrm{~km}$ north of the Kashima Port, considering correlations between the waves at two sites [31]. The interpolation was done only for the waves up to 2010, before the measurement interval was changed to a high frequency in 2011. In case of simultaneous missing measurements at both the sites, the data were treated as missing.

\subsection{Statistical Analysis}

We used 6826 beach profile data points observed between March 12, 1986 and June 2, 2020. We assessed the beach profile variability statistically using the mean profile and standard deviation (S.D.). The missing observations of the beach profile were associated with holidays before March 2011, but the frequency of the measurement changed from every weekday to once a week after April 2011. Considering the effect of the observation interval, the means and standard deviations were calculated by attaching a weighting to each time value, which was the average of the previous and subsequent intervals.

We used the decadal mean profiles and the S.D.s for the 1980s, 1990s, 2000s and 2010s to investigate the long-term variability in the beach profile. The monthly mean beach profile was the mean for the same calendar month through the 34-year study period. For example, the mean beach profile for April was the mean of the data for every April from 1986 to 2020. However, because the mean was not based on a continuous time series, it was strongly influenced by the long-term trend of the beach profile. Therefore, we decided not to use the monthly mean beach profiles in this study. To investigate the seasonal variability in the beach profile, we used the monthly S.D., which is the ensemble average of the S.D. for 1 month. For example, the S.D. for April is the root-mean-square of the S.D. for every April from 1986 to 2020. The sample sizes for the month were assumed to be the same among the years.

The annual and monthly means and the S.D.s of the significant wave height and period and water level were also calculated.

\section{Results and Discussion}

\subsection{Measured Beach Profile Summary}

Although the range between the maximum and minimum elevations during the observation over the 34 years was approximately $2 \mathrm{~m}$ at the measurement points from $\mathrm{P}-80 \mathrm{~m}$ to $\mathrm{P}-40 \mathrm{~m}$ of the backshore, it was more than $3 \mathrm{~m}$ at the other points, with a maximum of $5.21 \mathrm{~m}$ at P230 $\mathrm{m}$ (Figure 3a). In general, the beach morphology changes in response to the changes in wave conditions. Rapid and large-scale beach morphological changes (e.g., foreshore erosion) occur when large waves strike the coast, while slow and small beach morphological changes (e.g., foreshore accretion) occur when small waves are present. This pattern was seen in the observed data (Figure 4). The total sediment volume, which integrated all the elevations from P-115 m to P385 m, standardized by the total length of $500 \mathrm{~m}$ 
and mean beach profile, was relatively stable (Figure 5a), although there were complex changes in the beach profiles. The variation of the total sediment volume is due to the longshore sediment transport and the cross-shore sediment transport at the shore-side and offshore boundaries at P-115 m and P385 $\mathrm{m}$, respectively. The S.D. of the temporal change in total sediment volume was $0.29 \mathrm{~m}$ (Figure $5 \mathrm{a}$ ). The value is small enough compared with the variation of the profile (described later; mean S.D. of the elevation for all the points is $0.79 \mathrm{~m}$ ). Even if we assume that the variation of the total sediment volume is caused only by longshore sediment transport, changes in the beach profile at the Hasaki coast may be mainly caused by the cross-shore sediment transport.
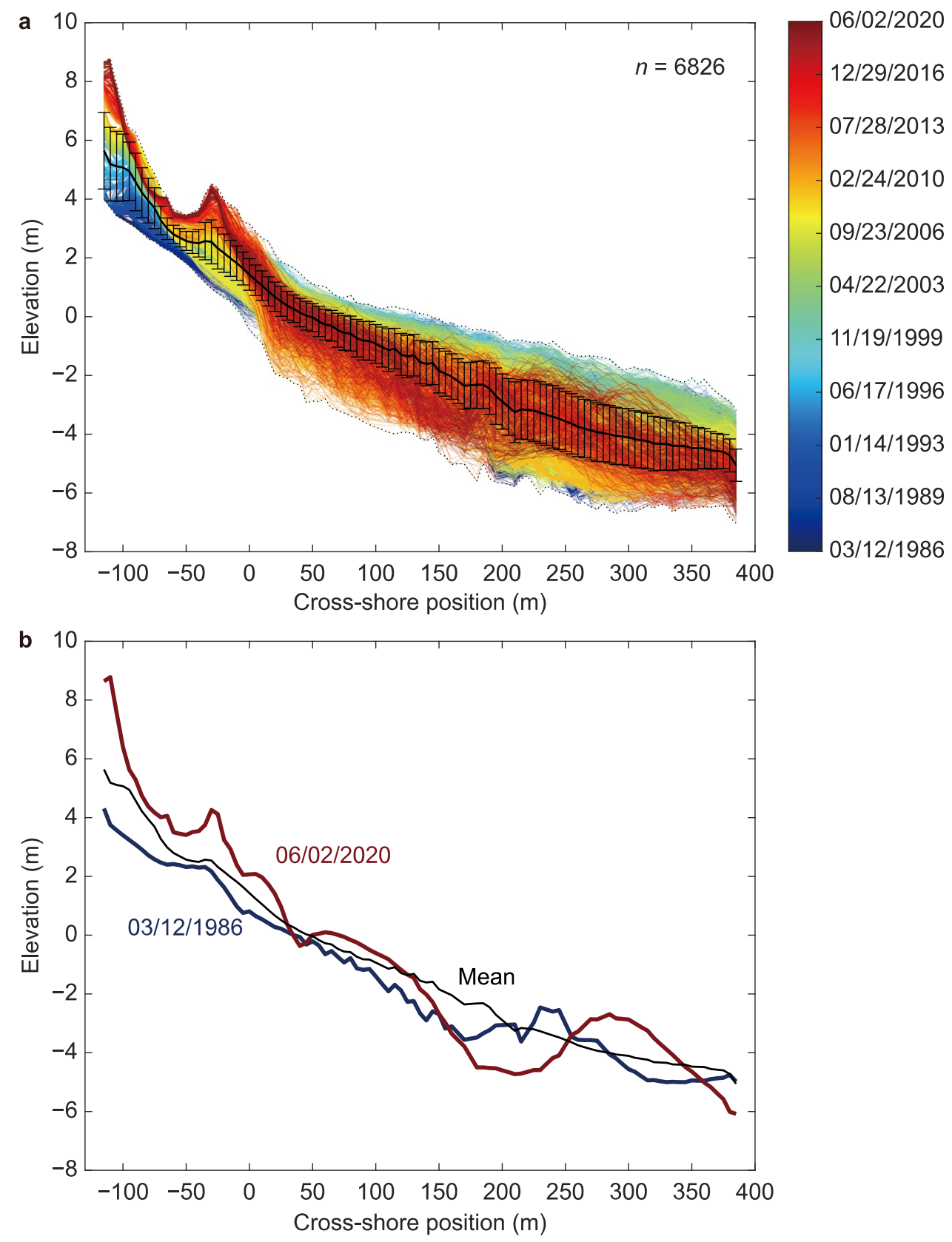

Figure 3. Observed beach profile. (a) Superposition of all the observed beach profiles from 1986 to 2020, and the mean beach profile \pm 1 S.D. the dot line refers to the envelope of the observed profiles; (b) beach profiles on March 12, 1986 (navy) and on June 2, 2020 (dark red) with the mean beach profile (black). 


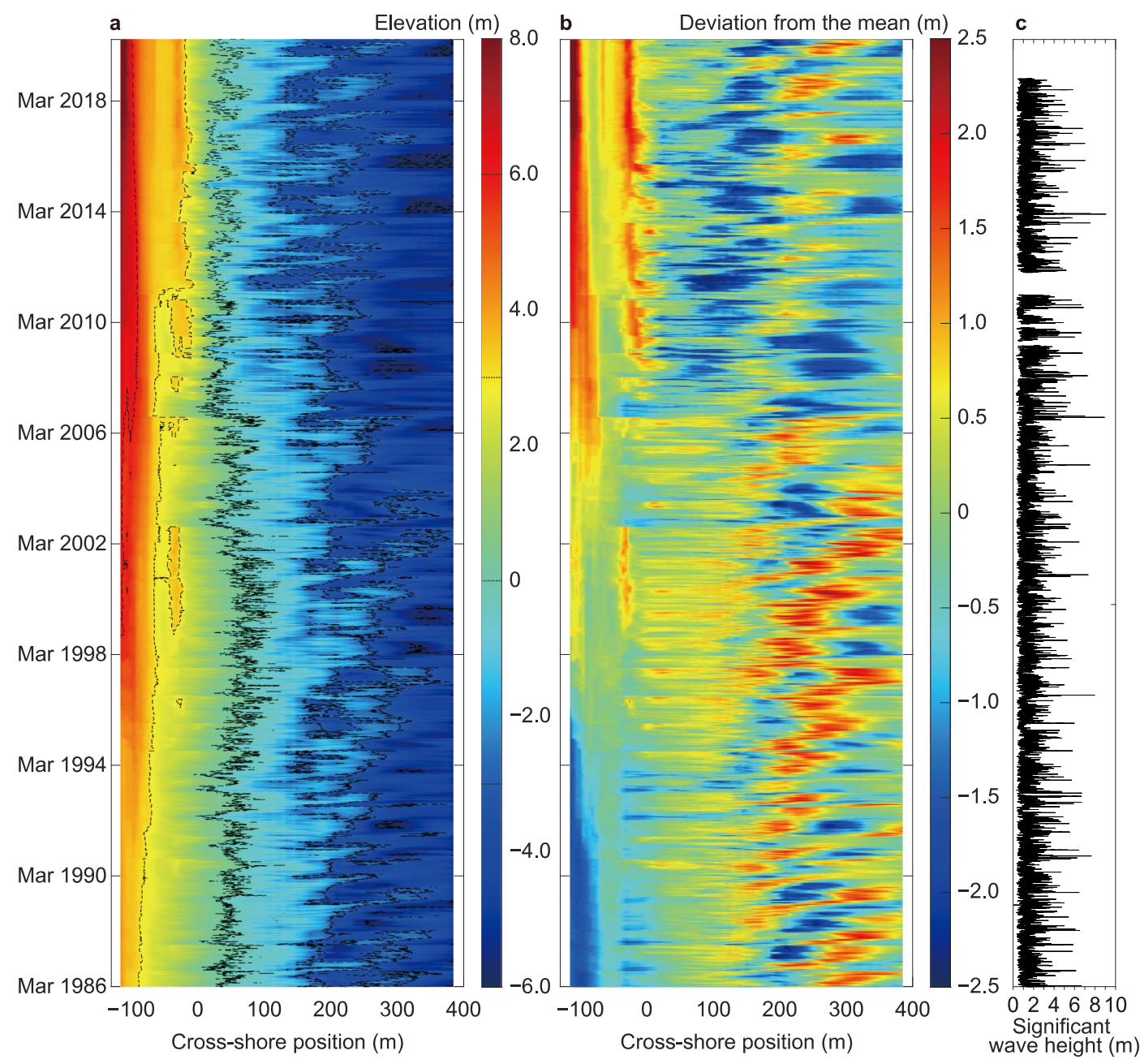

Figure 4. Time-series beach profile. (a) Time-series contour of observed beach profile; (b) time-series of deviation from the mean profile; (c) time series of significant wave height.

The most erosive event during the past 34 years was an extratropical cyclone that struck in 2006 and its associated high waves and extreme water levels. The approaching extratropical cyclone on October 6, 2006 caused significant wave heights of over $8 \mathrm{~m}$ and tidal anomalies more than $0.9 \mathrm{~m}$, resulting in large-scale erosion of the foreshore and backshore at the Hasaki coast [32].

The highest runup event was the tsunami wave that was caused by an earthquake in the Tohoku region in 2011. The $5 \mathrm{~m}$-high tsunami struck the coast on March 11, 2011. The beach profiles immediately before and after hitting the tsunami were observed, but it was reported that the beach profile change caused by the tsunami was relatively small [33], although the tsunami wave reached a higher height than most other waves.

In the most recent beach profile on June 2, 2020, the elevations on land $(z>0 \mathrm{~cm})$ had increased significantly compared with the beach profile at the beginning of the observations in 1986 (Figure 3b). The elevation landward of P-80 m increased almost monotonously over time (Figure 4a), and, in particular, the elevation at $\mathrm{P}-115 \mathrm{~m}$ increased by around $4 \mathrm{~m}$ from 1986 to 2020 (Figure 3b). The elevation at $\mathrm{P}-115 \mathrm{~m}$ was approximately $4 \mathrm{~m}$ in 1986, which was roughly the boundary between backshore and dune system [34]. The elevation at $\mathrm{P}-115 \mathrm{~m}$ is in now too high for waves to reach and the present-day change is driven only by wind. Therefore, we attribute the elevation increase to the development of the dune in this study. The development of the dunes may be partly related to accumulation around sand fences, which were erected landward outside of the measurement section several times to prevent onshore sediment transport to the hinterland and to protect the beach. 
However, the accumulated sediments are transported naturally by landward winds over a time scale of several decades [35]. A berm is formed near the limit of the wave runup, which is usually seen at a higher elevation than MHWS (Figure 3b; around the elevation of $200 \mathrm{~cm}$ ). The local increase in the elevation around $\mathrm{P}-30 \mathrm{~m}$ (Figures $3 \mathrm{~b}$ and 4 ) was caused by aeolian sediment transport. The sediment transported by the NNE wind, which is the predominant direction, was accumulated in the downwind sheltered area of the pier ramp. The influence of the pier ramp was seen only at three measurement points $(\mathrm{P}-35 \mathrm{~m}, \mathrm{P}-30 \mathrm{~m}$ and $\mathrm{P}-25 \mathrm{~m})$. In response to the profile changes described above, the sediment volume for the landward section $(<\mathrm{P} 0 \mathrm{~m})$ increased linearly with increasing elevations around the dunes and $\mathrm{P}-30 \mathrm{~m}$ (Figure $5 \mathrm{~b}$ ).
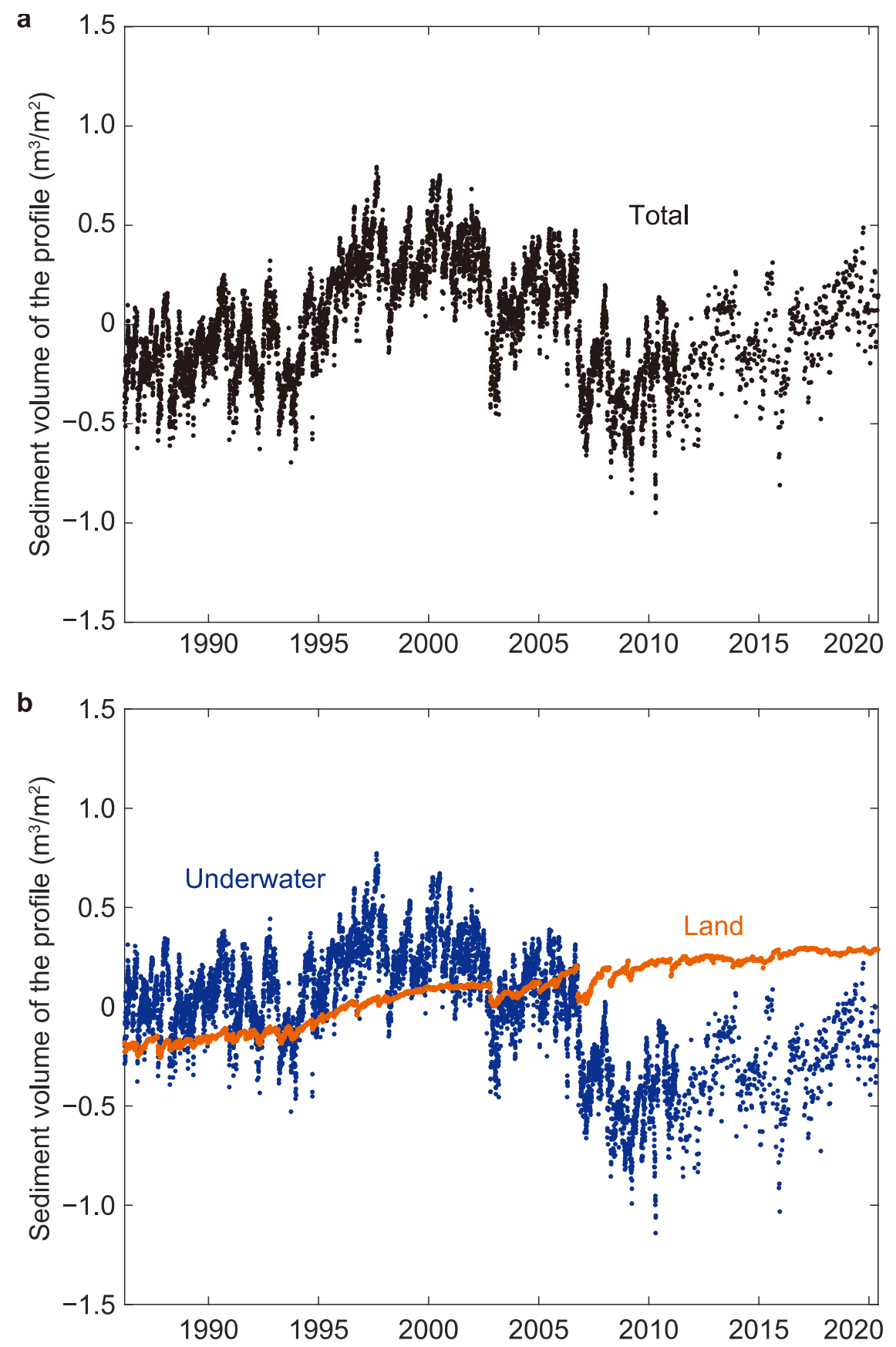

Figure 5. Time-series sediment volume. (a) Time series of total sediment volume; (b) time series of underwater sediment volume (blue) and of landward sediment volume (orange). 
The Hasaki coast mainly has a single longshore bar, forming a bar-trough morphology, which undulates by more than $1 \mathrm{~m}$ in height compared with the mean profile (Figure $4 \mathrm{~b}$ ). The observed bar behavior is consistent with the conceptual model [36], which consists of cyclical generation, seaward migration and degeneration. The bar emerges offshore from P180 m and moves offshore slowly on a multi-year scale until it disappears at around P385 $\mathrm{m}$ at the tip of the pier (Figure $4 \mathrm{~b}$ ). A new bar then reappears around P180 m. Kuriyama et al. [37] showed that the bar height increased offshore after P200 m, and analyzed the behavior. The cyclic period from the generation to the degeneration of the bar was approximately a year until 1993, but the period became longer after 1993 [37]. However, the period became unclear and the elevation in the bar top became lower after 2006 when the extratropical cyclone struck, causing a large-scale beach morphological change and deepening the water offshore of P180 m (Figure 4b). Since around 2018, the elevation of the bar top has become higher again. The sediment volume for the seaward section $(\geq \mathrm{P} 0 \mathrm{~m})$ increased slightly between 1994 and 1995, before decreasing significantly after the 2006 event. A slight recovery trend starting around 2013 was observed (Figure $5 b$ ).

\subsection{Statistical Results for All the Observations}

Deepwater waves incident on the coast had a mean significant wave height of $1.33 \mathrm{~m}$ and a mean significant wave period of $8.08 \mathrm{~s}$ (1986-2018). The beach slope of the mean beach profile was around 1/60; the mean elevation at the landward boundary $(\mathrm{P}-115 \mathrm{~m})$ and at the tip of the pier (P385 m) was $564 \mathrm{~cm}$ and $-505 \mathrm{~cm}$, respectively (Figures 3a and 6a). The elevation at P385 $\mathrm{m}$ is abruptly lower than the adjacent elevation because of scouring by the piles of the pier, which are supported by triple piles only at the tip of the pier.

The S.D. of the elevation at P-115 m, which is the landward boundary, was $1.3 \mathrm{~m}$ and it was the largest S.D. among all measurement points (Figures $3 a$ and $6 \mathrm{~b}$ ). The monthly S.D.s of the elevations on the landward side from P-50 m were small in all months, as discussed later. Therefore, the short-term variability (i.e., 1-month time scale) was small in the area. As a result, the large S.D. at P-115 m seems to arise from the long-term development of the dune, rather than from short-term accumulation and erosion. The S.D. of the elevation decreased to $0.31 \mathrm{~m}$ at $\mathrm{P}-60 \mathrm{~m}$ and this value was the smallest among all measurement points (Figures $3 \mathrm{a}$ and $6 \mathrm{~b}$ ). $\mathrm{P}-60 \mathrm{~m}$ point is located at around the habitat limit of dune vegetation [34]. This suggests that $\mathrm{P}-60 \mathrm{~m}$ is almost impervious to waves and the morphological changes are small. Slightly to seaward, the S.D. of the elevation at P-30 m was relatively large $(0.75 \mathrm{~m}$; Figures $3 \mathrm{a}$ and $6 \mathrm{~b}$ ). The large variation around $\mathrm{P}-30 \mathrm{~m}$ may be because of both local accumulation by aeolian sediment transport and berm formation and disappearance. The longshore bars move offshore and form a trough, which increases the relative height of the bar. In the underwater section, the bar movement resulted in large variations in elevation, especially from P180 m to P330 m. The S.D. of the elevation at P240 m was $1.1 \mathrm{~m}$ (Figures 3a and $6 \mathrm{~b}$ ). 

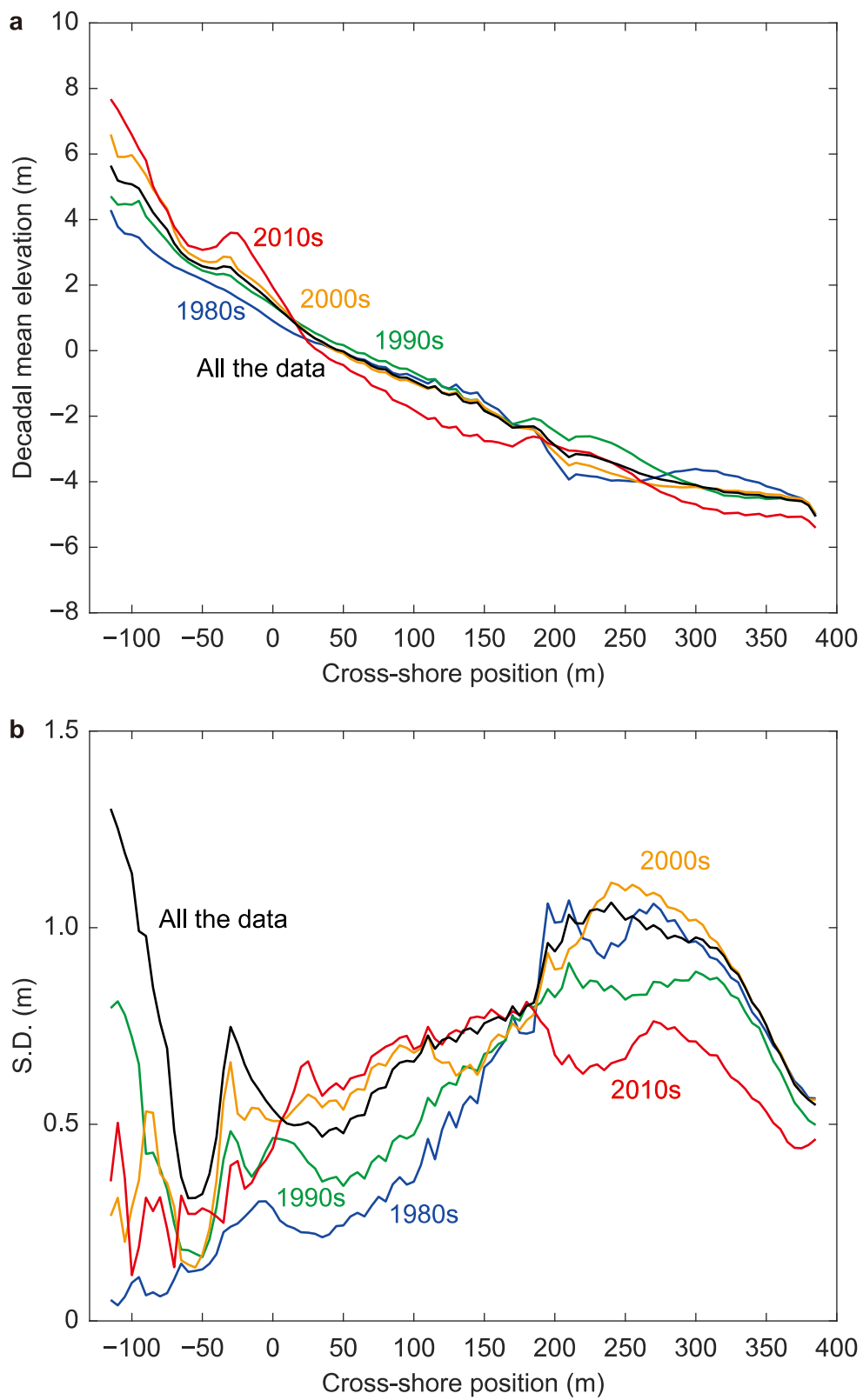

Figure 6. Decadal mean profile and the standard deviation. (a) Decadal mean profiles from the 1980s to the 2010s with the mean profile for all the data; (b) standard deviations of the elevations for each decade with that for all the data.

\subsection{Long-Term Variability of the Beach Profile}

The temporal change in the annual mean values of the significant wave heights and the periods was small over the whole study period (Figure 7a,b), although the future wave climate is predicted to change [38]. However, the short-term variability was large: the S.D. of the wave height even of the year with the least change (2004) was $0.58 \mathrm{~m}$ (Figure 7a). Although the short-term variability of the water level was also large because of the tidal fluctuations, the linear regression of observed annual mean water levels from 1986 to 2010 showed a rise of $4.1 \mathrm{~mm} /$ year at the coast (Figure 7c). Sea level rise shifts the equilibrium beach profile [39]. According to the Bruun rule [39], the equilibrium profile shifts upward and landward with rising sea level, leading to foreshore recession. Assuming that the mean slope of the equilibrium profile is $1 / 60$, the Bruun rule predicts that the equilibrium profile will shift to landward by around $5 \mathrm{~m}$ over 20 years. However, the decadal mean profile in this study did not show that the beach morphology had changed in accordance with the Bruun rule. This implies 
that the influences of waves and other factors are more dominant at the Hasaki coast at least over the past 30 years.
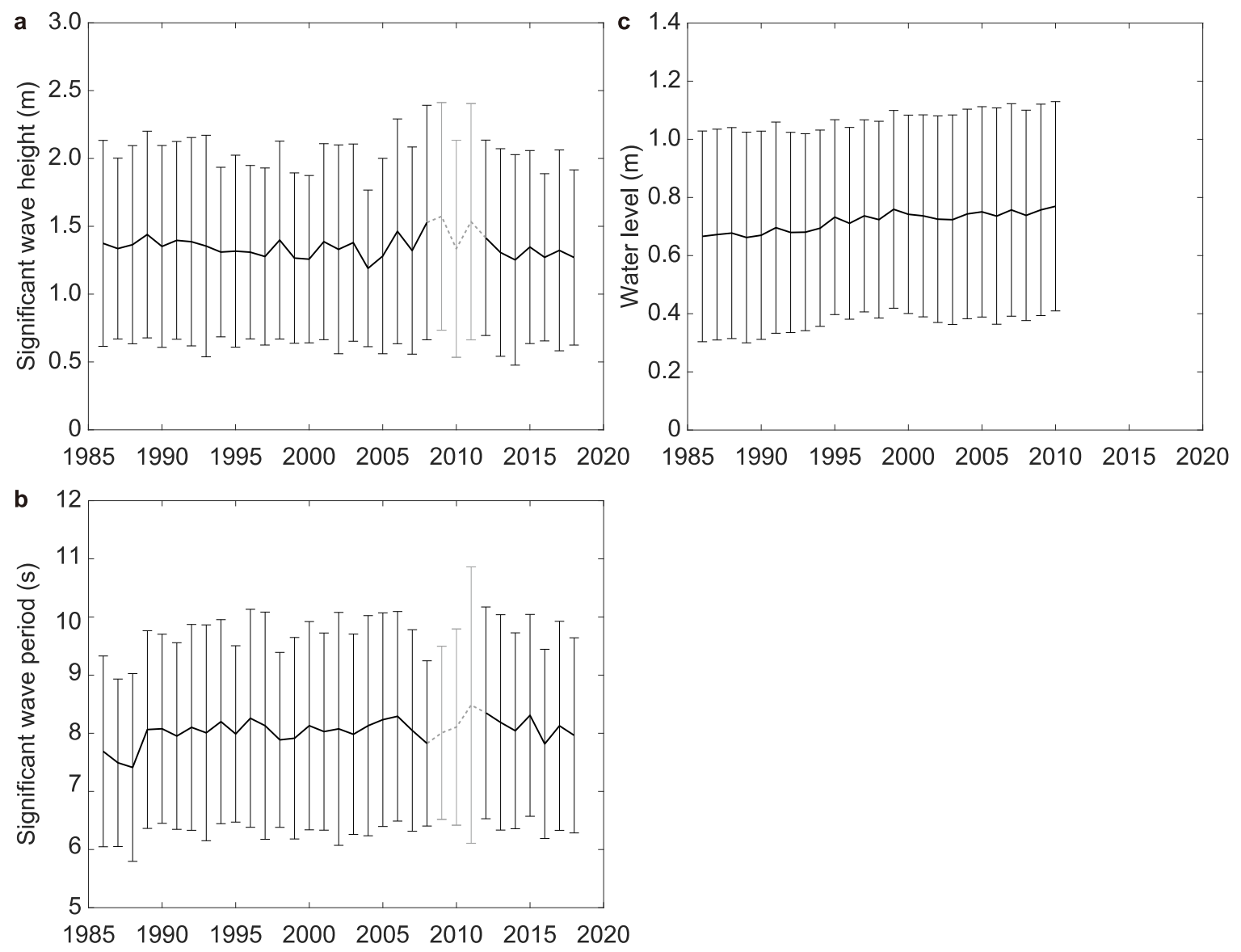

Figure 7. Annual mean of deepwater significant wave height and period and water level with \pm 1 S.D.

(a) Significant wave height; (b) significant wave period; (c) water level.

As mentioned above, the dune has developed over a long time scale. The decadal mean elevation at P-115 m was highest in the 2010s (Figure 6a). The dune developed significantly from the 1990s to the 2000s. The decadal mean elevation at P-30 m in the $2010 \mathrm{~s}$ was $75 \mathrm{~cm}$ higher than that of the 2000s (Figure 6a). Although the change at $\mathrm{P}-30 \mathrm{~m}$ was probably a direct result of the local accumulation by aeolian sediment transport described above, the trigger is unclear. At the same time, the underwater elevation decreased significantly in the 2010s, while the foreshore slope became steeper than previous foreshore slopes (Figure 6a). We divided the mean and S.D. in the 2000s into two periods-before and after the extratropical cyclone on October 7, 2006-to investigate the long-term impact of the cyclone on beach morphology, including the steepening of the foreshore slope. The data for the early and late 2000s were collected from the first day of 2000 to October 6, 2006 and October 7, 2006 to the last day of 2009, respectively. The results showed that the mean profiles and the S.D.s of the foreshore to the beach in the extremely shallow water (around P0 m to P110 m) in the early and late 2000s were similar to those in the 1990s and 2010s, respectively (Figure 8). In other words, the cyclone in 2006 may have changed the characteristics of the beach morphological changes, causing the foreshore to become steeper. The results are consistent with Kuriyama and Yanagishima [40] showing that the event caused regime shifts in the beach profile on the Hasaki coast. There was no clear difference in the mean profiles and S.D. around P-30 m between both periods (Figure 8), suggesting that the long-term characteristics of the morphological changes at P-30 m were not significantly changed by the 2006 event. We need to further investigate why the large accumulation at P-30 m occurred in the 2010s. 

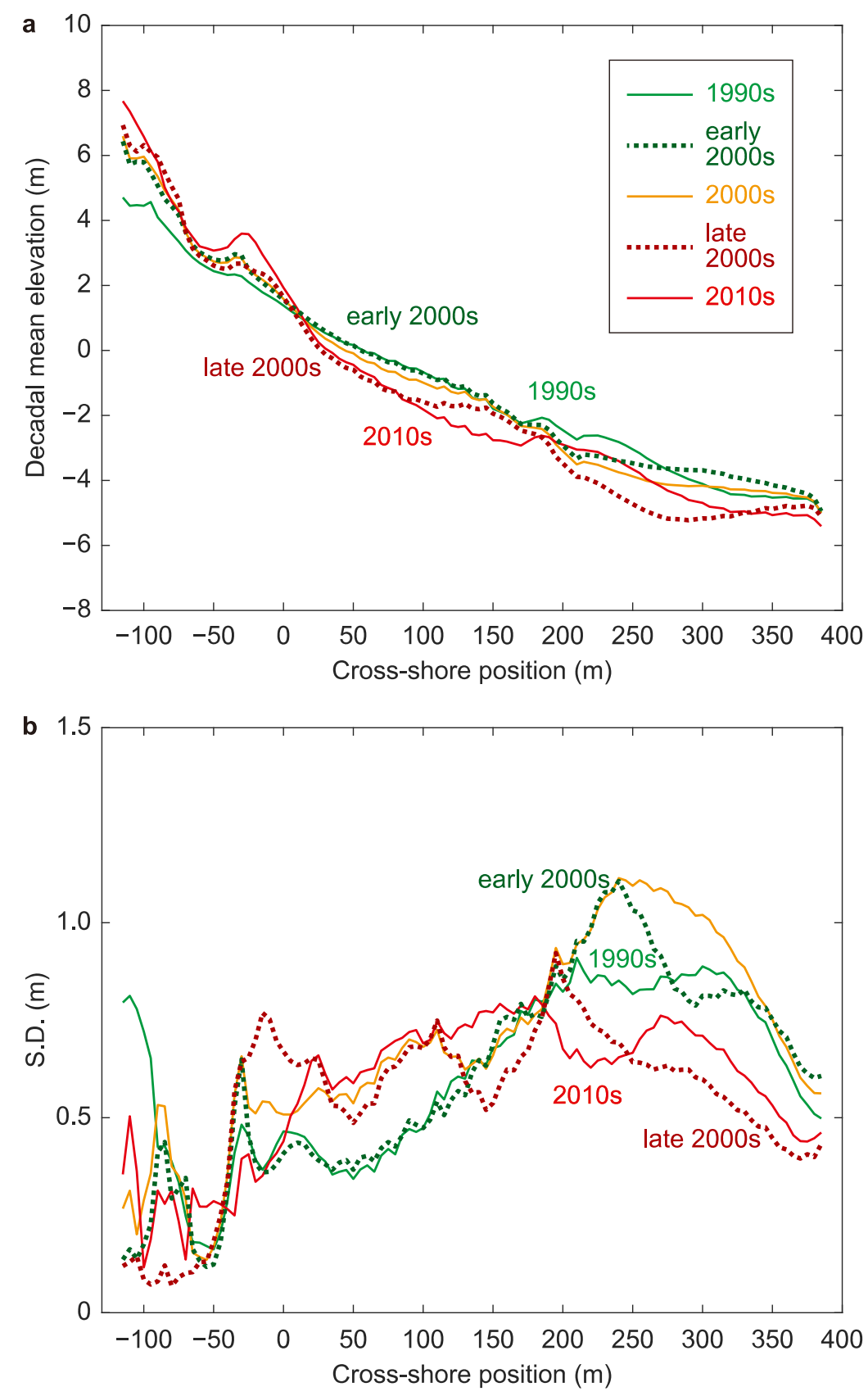

Figure 8. Comparison between the early and late 2000s. (a) Decadal mean profiles in the early and late 2000s divided from that of the mean profile in the 2000s; (b) standard deviations of the elevations corresponding to (a).

The S.D. of the elevation in the area offshore of P180 $\mathrm{m}$ where the bar is formed decreased sharply in the 2010s (Figure 6b), suggesting that the variation of the bar was small in that period. The trend in the late 2000s showed that the S.D.s offshore of P220 m slightly decreased compared with those in the early 2000s (Figure 8b). The S.D.s especially offshore from P300 m in the early and late 2000s were similar to those in the 1990s and 2010s, respectively. This suggests that the variability of the bar, especially offshore of P300 m, may have been decreased by the event in 2006. On the basis on the above changes after the 2006 event, the sediment volume for the seaward section was reduced, which resulted in low variability of the bar and a lower bar top height. As a result, it can be inferred that breaking waves at the bar tops were less likely to occur, which allowed larger waves to reach the shoreline, resulting in coarser foreshore sediment grain size [41] and a steeper foreshore slope. 
Because the impact of the extreme event in 2006 is still not entirely clear, the processes underlying this finding will need to be investigated further.

\subsection{Seasonal Variability of the Beach Profile}

Seasonal variations of the wave conditions in general cause seasonal variations in beach morphology. Monthly mean significant wave heights exceeded $1.5 \mathrm{~m}$ in February, March and October because of extratropical cyclones in early spring and typhoons in late summer (Figure 9a). The lowest monthly mean significant wave height was in July with a height of $0.90 \mathrm{~m}$ (Figure 9a). The monthly mean significant wave period was relatively stable throughout the year, but the period was slightly longer in August because of the effect of swell associated with typhoons (Figure 9b). Typhoons also occur frequently in September, but the effects of the swell were not represented in the mean value in September. Mean sea level was highest in September and lowest in April (Figure 9c).
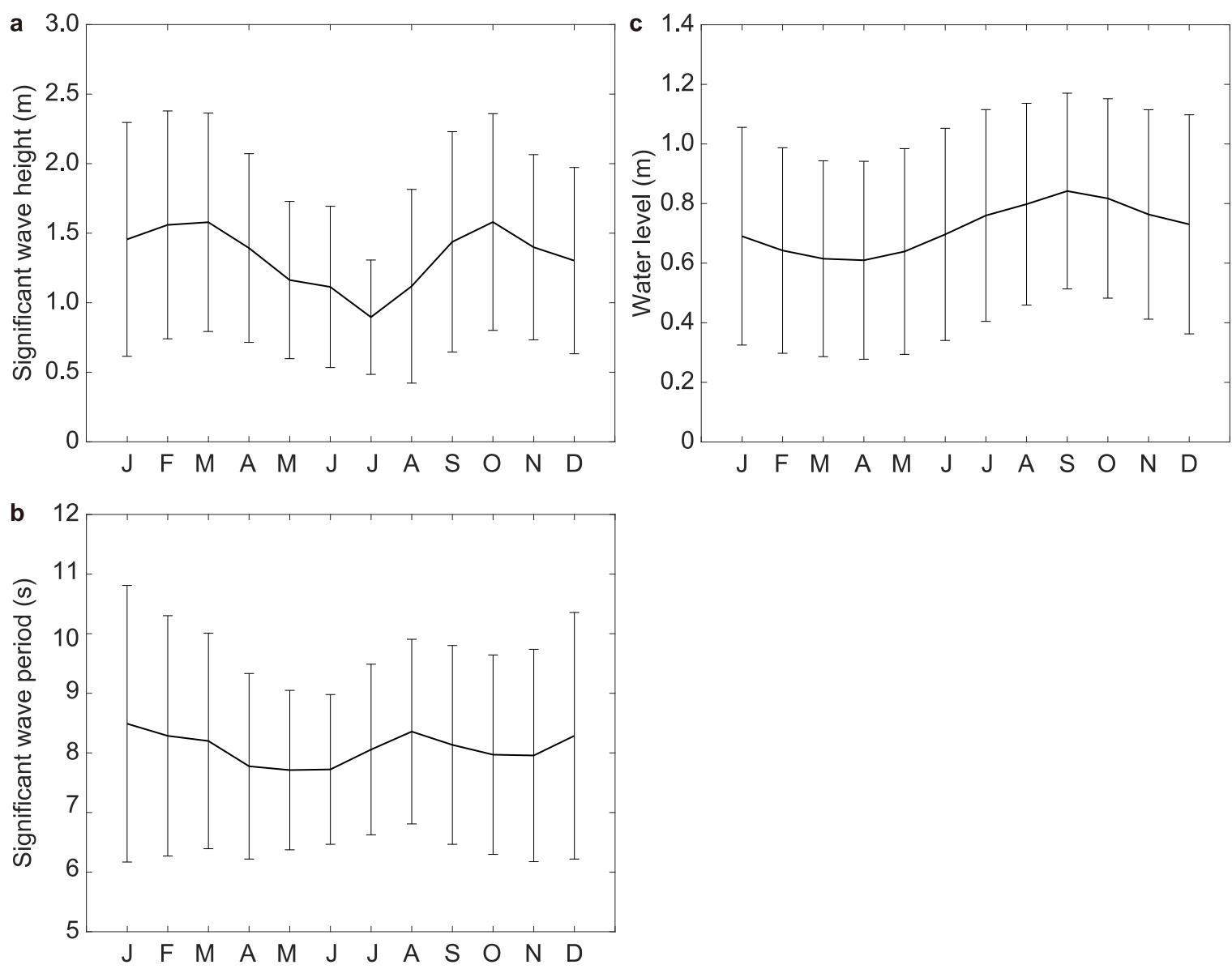

Figure 9. Monthly mean of deepwater significant wave height and period, and water level with \pm 1 S.D.

(a) Significant wave height; (b) significant wave period; (c) water level.

The S.D. of the elevation around P-30 m, where the berm is formed, was larger in September and October (Figure 10b), suggesting that berm erosion is caused by high waves with higher water level in this season. Because long period waves also affect berm erosion [21], the erosion in September might be affected by the typhoon swell. 

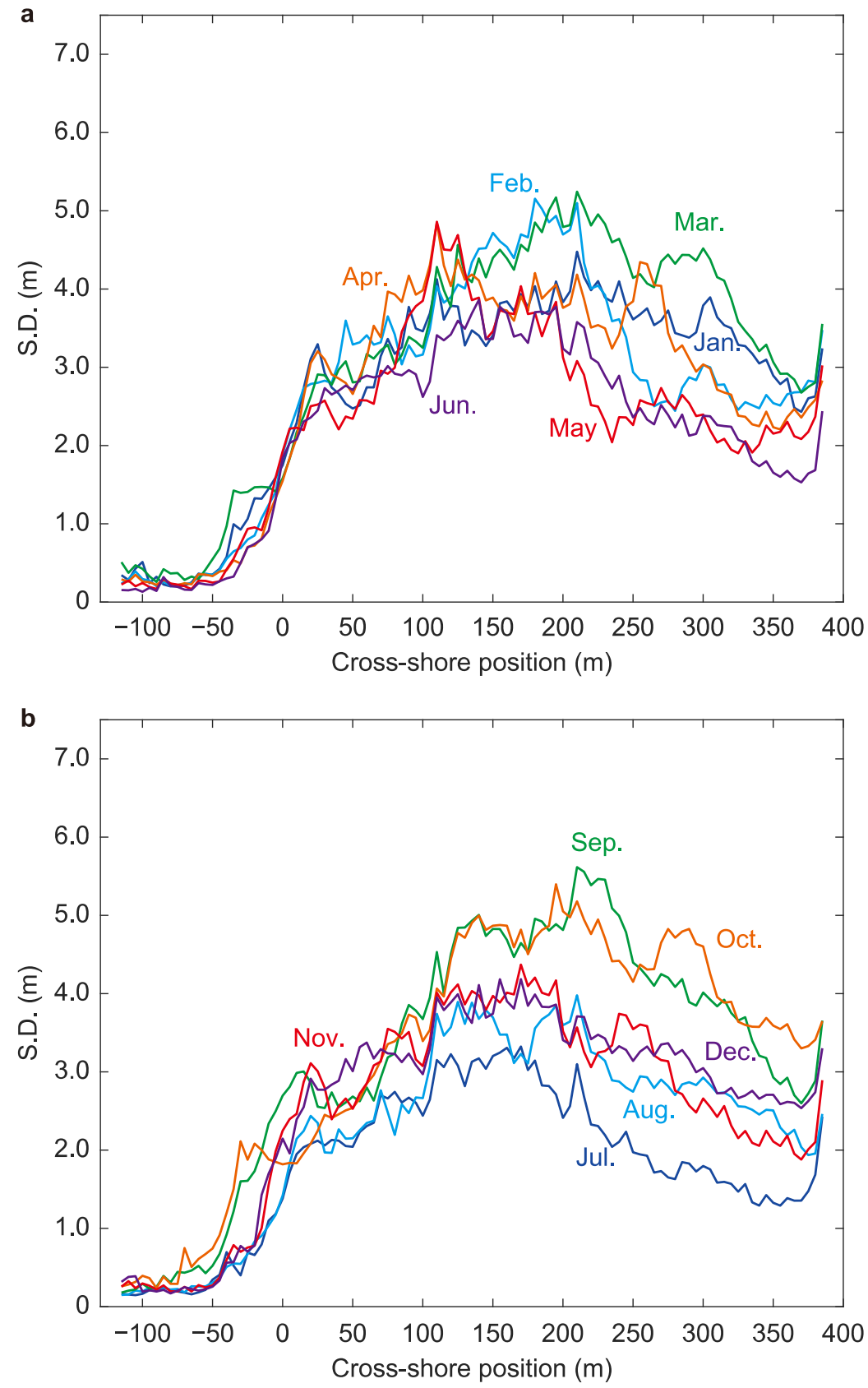

Figure 10. Monthly standard deviation of elevation (a) from January to June; (b) from July to December.

The S.D.s of the underwater elevation were relatively large, especially offshore of P180 m where the bar is formed (Figure 10), suggesting that the morphological changes associated with the bar behavior occur even on short time scales of around 1 month. In particular, the S.D. of the elevation around P200 m was largest in February, March, September and October, and smallest in July (Figure 10). The variability of the bar is expected to be larger during seasons with high waves and smaller during seasons with low waves.

The S.D. of the elevation at P385 $\mathrm{m}$ at the end of the pier was larger than that of the surrounding points (Figure 10). Local scouring and backfilling around the three piles occurred over short time scales. For the landward section, the monthly mean S.D. of the elevation landward from $\mathrm{P}-50 \mathrm{~m}$ was less than $0.1 \mathrm{~m}$ in any month (Figure 10), although there was a long-term trend of dune development, indicating that the short-term morphological changes were small. 


\section{Conclusions}

In this study, we presented the beach morphological changes obtained from long-term beach profile observations at the Hasaki coast since 1986. The beach profile was measured from the top of the dune to a water depth of approximately $6 \mathrm{~m}$ along a cross-shore transect of $500 \mathrm{~m}$ every weekday from March 1986 to March 2011 and once a week from April 2011 to the present. Such high-frequency and long-term observation of beach morphology is unique in the world. The observed 6826 beach profile data points reflected both long-term and short-term beach morphological changes such as dune development, foreshore morphological changes and bar movement. We analyzed long-term and seasonal variability using the mean beach profile and the standard deviation.

The dune has developed temporally, with the elevation at the landward boundary of the measurement point increasing by approximately $4 \mathrm{~m}$ from 1986 . The longshore bar was generated and disappeared repeatedly with the period of around a year from 1986 to 1993, but the period was then extended until 2006. In October 2006, extremely high waves and tidal anomalies from an extratropical cyclone caused a significant decrease in the underwater sediment volume. The elevation of the bar top became lower and the variations of the bar decreased. The foreshore slope became steeper after the 2006 event.

Seasonal beach profile changes were characterized by variability in the regions where the berm and bar formed. We suggest that berm erosion is caused by high waves with a higher water level in September and October. The variability of the bar is expected to be large during early spring and late summer when the waves are higher.

Although the mechanisms of the long-term and seasonal variability of the beach profile need to be examined in detail, this dataset identifies many phenomena that will trigger discussion among scientists and coastal engineers. It is expected that long-term beach observation data can be used to investigate various coastal phenomena and to validate long-term predictions using beach morphological change models.

Author Contributions: Conceptualization, M.B. and Y.K.; methodology, M.B. and Y.K.; software, M.B.; validation, M.B.; formal analysis, M.B.; investigation, M.B., S.N., T.K., S.-i.Y., Y.N. and Y.K.; resources, M.B., S.N., T.K., S.-i.Y., Y.N. and Y.K.; data curation, M.B., S.N. and S.-i.Y.; writing-original draft preparation, M.B.; writing-review and editing, M.B., S.N., T.K., S.-i.Y., Y.N. and Y.K.; visualization, M.B.; supervision, Y.K.; project administration, S.N.; funding acquisition, M.B., S.N. and Y.K. All authors have read and agreed to the published version of the manuscript.

Funding: This research was funded by JSPS KAKENHI (grant number 19H02244 and 19K15106) and was supported by the Ministry of Land, Infrastructure, Transport and Tourism, Japan.

Acknowledgments: The sea-water level data and the deep-water wave data were provided by the Ministry of Land, Infrastructure, Transport and Tourism of Japan. The authors would like to express their deepest gratitude to all the staff of the Hazaki Oceanographical Research Station for their long-term field observations.

Conflicts of Interest: The authors declare no conflict of interest.

\section{References}

1. Stronge, W.B. Economic Value of Beaches. In Encyclopedia of Earth Science Series; Schwartz, M.L., Ed.; Springer: Dordrecht, The Netherlands, 2005; pp. 401-403.

2. Roelvink, J.A.; Reniers, A.; van Dongeren, A.R.; van Thiel de Vries, J.S.M.; McCall, R.; Lescinski, J. Modeling storm impacts on beaches, dunes and barrier islands. Coast. Eng. 2009, 56, 1133-1152. [CrossRef]

3. Pape, L.; Kuriyama, Y.; Ruessink, B.G. Models and scales for cross-shore sandbar migration. J. Geophys. Res. 2010, 115, F03043. [CrossRef]

4. Yates, M.L.; Guza, R.T.; O'Reilly, W.C. Equilibrium shoreline response: Observations and modeling. J. Geophys. Res. 2009, 114, C09014. [CrossRef]

5. Larson, M.; Hanson, H.; Kraus, N.C. Analytical solutions of one-line model for shoreline change near coastal structures. J. Waterw. Port Coast. Ocean Eng. 1997, 123, 180-191. [CrossRef] 
6. Vitousek, S.; Barnard, P.L.; Limber, P.; Erikson, L.; Cole, B. A model integrating longshore and cross-shore processes for predicting long-term shoreline response to climate change. J. Geophys. Res. Earth Surf. 2017, 122, 782-806. [CrossRef]

7. Banno, M.; Kuriyama, Y. Supermoon drives beach morphological changes in the swash zone. Geophys. Res. Lett. 2020, in press.

8. Ruessink, B.G.; Wijnberg, K.M.; Holman, R.A.; Kuriyama, Y.; van Enckevort, I.M.J. Intersite comparison of interannual nearshore bar behavior. J. Geophys. Res. 2003, 108, 3249. [CrossRef]

9. Ruessink, B.G.; Kuriyama, Y.; Reniers, A.J.H.M.; Roelvink, J.A.; Walstra, D.J.R. Modeling cross-shore sandbar behavior on the timescale of weeks. J. Geophys. Res. 2007, 112, F03010. [CrossRef]

10. Matsumoto, H.; Young, A.; Guza, R.T. Observations of surface cobbles at two southern California beaches. Mar. Geol. 2020, 419, 106049. [CrossRef]

11. Barnard, P.; Short, A.; Harley, M.; Splinter, K.D.; Vitousek, S.; Turner, I.L.; Allan, J.; Banno, M.; Bryan, K.R.; Doria, A.; et al. Coastal vulnerability across the Pacific dominated by El Niño/Southern Oscillation. Nat. Geosci. 2015, 8, 801-807. [CrossRef]

12. Vitousek, S.; Barnard, P.L.; Limber, P. Can beaches survive climate change? J. Geophys. Res. Earth Surf. 2017, 122, 1060-1067. [CrossRef]

13. Lippmann, T.C.; Holman, R.A. The spatial and temporal variability of sandbar morphology. J. Geophys. Res.-Oceans 1990, 95, 11575-11590. [CrossRef]

14. Larson, M.; Kraus, N.C. Temporal and spatial scales of beach profile change, Duck, North Carolina. Mar. Geol. 1994, 117, 75-94. [CrossRef]

15. Nicholls, R.J.; Birkemeier, W.A.; Lee, G. Evaluation of depth of closure using data from Duck, NC, USA. Mar. Geol. 1998, 148, 179-201. [CrossRef]

16. Harley, M.D.; Turner, I.L.; Short, A.D.; Ranasinghe, R. Assessment and integration of conventional, RTK-GPS and image-derived beach survey methods for daily to decadal coastal monitoring. Coast. Eng. 2011, 58, 194-205. [CrossRef]

17. Turner, I.L.; Harley, M.; Short, A.D.; Simmons, J.A.; Bracs, M.A.; Phillips, M.S.; Splinter, K.D. A multi-decade dataset of monthly beach profile surveys and inshore wave forcing at Narrabeen, Australia. Sci. Data 2016, 3, 160024. [CrossRef]

18. Short, A.; Trenbanis, A.C. Decadal scale patterns in beach oscillation and rotation Narrabeen Beach, Australia time series, PCA and wavelet analysis. J. Coast. Res. 2004, 20, 523-532. [CrossRef]

19. Tsuchiya, Y.; Shirai, T.; Yamashita, T. Long-term changes in beach profiles at Ogata Coast. Bull. Disaster Prev. Res. Inst. 1982, 32, 171-187.

20. Hashimoto, H.; Uda, T. Field investigation of beach profile changes and the analysis using empirical eigenfunction. Proc. 18th Int. Conf. Coast. Eng. 1982, 1369-1384.

21. Katoh, K.; Yanagishima, S. Berm erosion due to long period waves. In Proceedings of the 22nd International Conference on Coastal Engineering, Delft, The Netherlands, 2-6 July 1990; pp. 2073-2086.

22. Kuriyama, Y.; Banno, M.; Suzuki, T. Linkages among interannual variations of shoreline, wave and climate at Hasaki, Japan. Geophys. Res. Lett. 2012, 39, L06604. [CrossRef]

23. Kuriyama, Y.; Yanagishima, S. Investigation of medium-term barred beach behavior using 28-year beach profile data and Rotated Empirical Orthogonal Function analysis. Geomorphology 2016, 261, $236-243$. [CrossRef]

24. Thom, B.; Hall, W. Behaviour of beach profiles during accretion and erosion dominated periods. Earth Surf. Process. Landf. 1991, 16, 113-127. [CrossRef]

25. McLean, R.; Shen, J.S. From foreshore to foredune: Foredune development over the last 30 years at Moruya Beach, New South Wales, Australia. J. Coast. Res. 2006, 22, 28-36. [CrossRef]

26. Tamura, T.; Oliver, T.S.N.; Cunningham, A.C.; Woodroffe, C.D. Recurrence of extreme coastal erosion in SE Australia beyond historical timescales inferred from beach ridge morphostratigraphy. Geophys. Res. Lett. 2019, 46, 4705-4714. [CrossRef]

27. Katoh, K.; Yanagishima, S. Changes of sand grain distribution in the surf zone. Proc. Coast. Dyn. 1995, 355-364.

28. Banno, M.; Takewaka, S.; Kuriyama, Y. Multidecadal shoreline evolution due to large-scale beach nourishment -Japanese Sand Engine? Proc. Coast. Dyn. 2017, 820-829.

29. Katoh, K. Hazaki Oceanographical Research Station (HORS). Mar. Technol. Soc. J. 1997, 31, 49-56. 
30. Kuriyama, Y. Medium-term bar behavior and associated sediment transport at Hasaki, Japan. J. Geophys. Res.-Oceans 2002, 107, 12. [CrossRef]

31. Katoh, K.; Yanagishima, S.; Isogami, T.; Murakami, H. Wave set-up near the shoreline-Field observation at HORF. Rep. Port Harbour Res. Inst. 1989, 28, 1-41.

32. Galal, E.M.; Takewaka, S. The influence of alongshore and cross-shore wave energy flux on large- and small-scale coastal erosion patterns. Earth Surf. Process. Landf. 2011, 36, 953-966. [CrossRef]

33. Kuriyama, Y.; Takahashi, K.; Yanagishima, S.; Tomita, T. Beach profile change at Hasaki, Japan, caused by 5-m-high tsunami due to the 2011 off the Pacific coast of Tohoku Earthquake. Mar. Geol. 2014, 355, 234-243. [CrossRef]

34. Kuriyama, Y.; Mochizuki, N.; Nakashima, T. Influence of vegetation on aeolian sand transport rate from a backshore to a foredune at Hasaki, Japan. Sedimentology 2005, 52, 1123-1132. [CrossRef]

35. Yokobori, M.; Kuriyama, Y.; Shimozono, T.; Tajima, Y. Numerical simulation of volume change of the backshore induced by cross-shore aeolian sediment transport. J. Mar. Sci. Eng. 2020, 8, 438. [CrossRef]

36. Ruessink, B.G.; Kroon, A. The behavior of a multiple bar system in the nearshore zone of Terschelling, The Netherlands: 1965-1993. Mar. Geol. 1994, 121, 187-197. [CrossRef]

37. Kuriyama, Y.; Ito, Y.; Yanagishima, S. Medium-term variations of bar properties and their linkages with environmental factors at Hasaki, Japan. Mar. Geol. 2008, 248, 1-10. [CrossRef]

38. Hemer, M.; Fan, Y.; Mori, N.; Semedo, A.; Wang, X.L. Projected changes in wave climate from a multi-model ensemble. Nat. Clim. Chang. 2013, 3, 471-476. [CrossRef]

39. Bruun, P. SLR as a cause of shore erosion. J. Waterw. Harbors Div. 1962, 88, 117-132.

40. Kuriyama, Y.; Yanagishima, S. Regime shifts in the multi-annual evolution of a sandy beach profile. Earth Surf. Process. Landf. 2018, 43, 3133-3141. [CrossRef]

41. Yanagishima, S. Characteristic of grain size change at the Hasaki Coast. Tech. Note Port Airport Res. Inst. 2016, 1317, 1-42.

Publisher's Note: MDPI stays neutral with regard to jurisdictional claims in published maps and institutional affiliations.

(C) 2020 by the authors. Licensee MDPI, Basel, Switzerland. This article is an open access article distributed under the terms and conditions of the Creative Commons Attribution (CC BY) license (http://creativecommons.org/licenses/by/4.0/). 